\title{
PENGARUH RESPONSIVENESS, EASE OF USE, RELIABILITY, CONVENIENCE, FULFILLMENT, DAN SECURITY AND PRIVACY TERHADAP CUSTOMER SATISFACTION MANDIRI MOBILE
}

\author{
SURAHMAN PUJIANTO \\ STIE Trisakti \\ surahman@dosen.stietrisakti.ac.id
}

\begin{abstract}
The purpose of this research is to test and analyze empirically the influence of Responsiveness, Ease of Use, Reliability, Convenience, Fulfillment, Security and Privacy toward Customer Satisfaction. The research design used in descriptive research and causality research, in which variables are measured with 5 points Likert scale. This research used primary data which collected by questionnaire. The sampling in the study was purposive sampling and used 130 respondents. The research data is processed with SPSS statistics program. The result of this research has shown that Responsiveness, Ease of Use, Reliability, Convenience, Security and Privacy have influence to the Customer Satisfaction. While Fulfillment do not has influence to customer Satisfaction.
\end{abstract}

Keywords: Responsiveness, ease of use, reliability, convenience, fulfillment, security and privacy, customer satisfaction, mobile banking

Abstrak: Tujuan penelitian adalah untuk menguji dan menganalisis secara empiris pengaruh Responsiveness, Kemudahan Penggunaan, Keandalan, Kenyamanan, Pemenuhan, Keamanan dan Privasi terhadap Kepuasan Pelanggan. Desain penelitian yang digunakan dalam penelitian deskriptif dan penelitian kausalitas, di mana variabel diukur dengan skala likert 5 poin. Penelitian ini menggunakan data primer yang dikumpulkan dengan kuesioner. Pengambilan sampel dalam penelitian ini adalah purposive sampling dan menggunakan 130 responden. Data penelitian diproses dengan program statistik SPSS. Hasil penelitian ini menunjukkan bahwa Responsiveness, Kemudahan Penggunaan, Keandalan, Kenyamanan, Keamanan dan Privasi memiliki pengaruh terhadap Kepuasan Pelanggan. Sedangkan Pemenuhan tidak memiliki pengaruh terhadap Kepuasan pelanggan.

Kata kunci: Responsiveness, kemudahan penggunaan, keandalan, kenyamanan, pemenuhan, keamanan dan privasi, kepuasan pelanggan, mobile banking

\section{PENDAHULUAN}

Kemajuan dan perkembangan teknologi yang diiringi dengan perkembangan sistem informasi berbasis teknologi terjadi begitu pesat di era globalisasi ini. Perkembangan teknologi informasi yang terjadi sangat didukung dengan munculnya internet. Berdasarkan data dari Asosiasi Penyelenggara Jasa Internet Indonesia
(APJII), sampai saat ini pengguna internet di Indonesia pada tahun 2016 telah mencapai 132,7 juta (51,8 \%) dari total populasi penduduk Indonesia yang mencapai 256 juta pengguna.

Budaya internet yang semakin berkembang juga berpengaruh terhadap pesatnya peningkatan jumlah pengguna smartphone di Indonesia. Jumlah pengguna smartphone di Indonesia mencapai 69,4 juta 
pengguna dari total penduduk 250 juta orang. Lembaga riset digital marketing Emarketer memperkirakan pada 2018 jumlah pengguna aktif smartphone di Indonesia lebih dari 100 juta orang. Perkembangan dan kesuksesan dalam teknologi ini dimanfaatkan oleh para industri perbankan untuk meciptakan alat bersaing dalam ekonomi yang lebih kompetitif. Sektor perbankan berlomba-lomba menggunakan teknologi informasi dan komunikasi untuk menawarkan pelayanan yang lebih baik bagi pelanggan mereka yaitu, dengan meluncurkan media layanan transaksi perbankan berbasis teknologi atau yang dikenal dengan E-banking. E-Banking atau Electronic Banking merupakan layanan perbankan yang menggunakan media elektronik sebagai perantaranya. Tujuan dari Electronic Banking adalah sebagai sarana penyediaan multi channel dan juga dapat menghemat biaya transaksi bank, nasabah lebih bebas, mudah, cepat dan memberikan kenyamanan bertransaksi 24 jam sehari dimanapun nasabah berada.

Salah satu produk E-Banking yang terdapat dalam bank adalah fasilitas mobile banking. Mobile banking adalah aplikasi perbankan yang perlu diunduh dalam perangkat mobile yang memiliki fungsi untuk memudahkan nasabah melakukan transaksi perbankan. Layanan M-Banking membuka kesempatan bagi nasabah untuk melakukan transaksi perbankan melalui perangkat handphone atau Personal Data Assistant (PDA). Dengan adanya berbagai kemudahan layanan m-banking diharapkan nasabah akan memperoleh kepuasan dalam menggunakan berbagai macam produk dan jasa yang disediakan oleh bank. Penelitian ini bertujuan untuk menjawab pertanyaan apakah Responsiveness, Ease of Use, Reliability, Convenience, Fulfillment, dan Security And Privacy memberikan pengaruh terhadap Customer Satisfaction pada pengguna Mandiri Mobile Banking. Penelitian ini dapat memberikan kontribusi bagi perusahaan untuk mengetahui mengenai respon atau tanggapan konsumen mengenai kinerja dari layanan yang disediakan sehingga manajemen Bank Mandiri dapat lebih mengembangkan produk dan jasa sesuai apa yang dibutuhkan dan diinginkan oleh konsumennya.

\section{Responsiveness dan Customer Satisfaction}

Menurut Zeithaml et al. (2002) responsiveness adalah kesigapan dalam memberikan layanan dan bantuan kepada pelanggan. perusahaan harus bisa siap dalam segala kondisi yang mungkin terjadi didalam layanan yang mereka sediakan. Ada pencegahan atau penanganan yang bisa dilakukan atau berikan untuk membantu konsumen. Dengan begitu konsumen akan merasa terlayani dengan baik. Dari penjelasan diatas, maka hipotesis yang dibuat adalah:

$\mathrm{H}_{1}$ Terdapat pengaruh Responsiveness

terhadap Customer Satisfaction Mandiri

Mobile

\section{Ease of Use dan Customer Satisfaction}

Davis $(1989,985)$ mendefinisikan ease of use adalah tingkat kemudahan penggunaan suatu sistem tanpa adanya upaya yang perlu dikeluarkan. Saat suatu layanan memiliki tingkat kemudahan yang besar, maka hal itu akan mendorong kemauan konsumen untuk menggunakan dan beradaptasi dengan layanan yang disediakan. Dari penjelasan diatas, maka hipotesis yang dibuat adalah:

$\mathrm{H}_{2}$ Terdapat pengaruh Ease of Use terhadap

Customer Satisfaction Mandiri Mobile

\section{Reliability dan Customer Satisfaction}

Parasuraman et al. (1988) mendefinisikan reliability adalah keandalan suatu produk atau sistem sehingga dapat bekerja dengan baik. Dalam lingkungan layanan mobile banking, Reliability berbicara mengenai seberapa akurat dan andal suatu layanan, seberapa baik layanan itu dapat berfungsi setiap waktu, tidak adanya error atau kesalahan yang mungkin terjadi dan konsisten dalam pelayanan. Reliability dalam suatu layanan mempengaruhi kepuasan yang dirasakan konsumen dalam 
layanan tersebut. Dari penjelasan diatas, maka hipotesis yang dibuat adalah:

$\mathrm{H}_{3}$ Terdapat pengaruh Reliability terhadap Customer Satisfaction Mandiri Mobile

\section{Convenience dan Customer Satisfaction}

Berry et al. (2002) menyatakan convenience yang dirasakan oleh konsumen menjadi faktor yang penting. Karena konsumen merasa sulit atau enggan menggunakan suatu layanan yang mereka rasa akan memakan banyak waktu dan usaha mereka. Konsumen menginginkan layanan yang memberi kemudahan dan efisiensi. Dari pengertian diatas dapat disimpulkan bahwa Convenience adalah perkiraan waktu dan usaha yang harus dikeluarkan oleh konsumen dalam menggunakan suatu layanan. Dari penjelasan diatas, maka hipotesis yang dibuat adalah:

$\mathrm{H}_{4}$ Terdapat pengaruh Convenience terhadap Customer Satisfaction Mandiri Mobile

\section{Fulfillment dan Customer Satisfaction}

Parasuraman et al. (2005) menyatakan fulfillment dapat diartikan sebagai pemenuhan layanan kepada pelanggan sesuai dengan apa yang telah dijanjikan. Fulfillment merupakan salah satu dimensi yang penting yang perlu diperhatikan dalam kualitas layanan mobile banking. Karena saat seorang konsumen merasa apa yang diinginkan nya lewat layanan yang diberikan terpenuhi atau saat suatu layanan bisa memberikan layanan sesuai dengan apa yang telah dijanjikan maka konsumen tentu akan merasa puas atas layanan tersebut. Dari penjelasan diatas, maka hipotesis yang dibuat adalah:

$\mathrm{H}_{5}$ Terdapat pengaruh Fulfillment terhadap Customer Satisfaction Mandiri Mobile

\section{Security and Privacy dan Customer Satisfaction}

Menurut Zeithaml et al. (2002) security and privacy merupakan hal yang perlu diperhatikan oleh perusahaan karena hal tersebut merupakan sesuatu yang penting bagi konsumen. Dengan menjaga Security and Privacy dari konsumen diharapkan konsumen akan merasa aman dan nyaman dalam menggunakan layanan dari Mandiri Mobile. Sehingga konsumen akan tetap menggunakan layanan mobile banking mandri karena konsumen percaya dengan layanan yang ditawarkan. Ada kepercayaa yang timbul terhadap layanan. Dari penjelasan diatas, maka hipotesis yang dibuat adalah:

$\mathrm{H}_{6}$ Terdapat pengaruh Security and Privacy terhadap Customer Satisfaction Mandiri Mobile

\section{METODE PENELITIAN}

Jumlah sampel yang diambil oleh peneliti adalah sebanyak 130 responden dimana sampel tersebut didapatkan melalui penyebaran kuisioner secara langsung maupun melalui google form. Responden dalam penelitian ini adalah orang-orang yang menggunakan mobile banking Mandiri Mobile dengan kriteria:

1. Responden berjenis kelamin pria dan wanita

2. Responden dengan jabatan Manager level up atau seorang wiraswasta

3. Responden dengan penghasilan Rp 20.000.000,- atau lebih. Pemilihan responden dengan penghasilan minimal Rp20.000.000,- dimaksudkan responden dengan penghasilan tersebut tidak menggunakan mobile banking hanya untuk kebutuhan kantor tapi merupakan individual user

4. Punya mobile banking Mandiri dan Mobile Banking lain. Karena reponden dianggap mumpuni dalam menilai kinerja layanan mobile banking yang digunakan

Berikut ini disajikan karakteristik dari responden yang digunakan dalam penelitian: 
Tabel 1 Karakteristik Responden

\begin{tabular}{llr}
\hline Keterangan & & Jumlah \\
\hline Jenis Kelamin & Pria & 62 \\
Usia & Wanita & 68 \\
& $21-30$ tahun & 50 \\
& $31-40$ tahun & 56 \\
& $41-50$ tahun & 18 \\
Pekerjaan & $>=51$ tahun & 6 \\
& wiraswasta & 90 \\
Pendidikan & manager Ivl up & 37 \\
& lainnya & 3 \\
& SD & 2 \\
& SMP & 6 \\
& SMA & 35 \\
& DIPLOMA & 5 \\
& S1 & 65 \\
& S2 & 14 \\
\hline
\end{tabular}

Berikut ini disajikan mengenai pengukuran dari setiap variabel penelitian:

Tabel 2 Variabel dan Pengukurannya

\begin{tabular}{|c|c|c|c|}
\hline No. & Variabel & Indikator Pernyataan & Skala \\
\hline 1 & $\begin{array}{l}\text { Responsiveness } \\
\left(X_{1}\right)\end{array}$ & $\begin{array}{l}\text { 1. Sistem Mandiri Mobile merespon transaksi } \\
\text { perbankan yang tidak benar dengan cepat } \\
\text { 2. Mandiri Mobile menyelesaikan masalah saya } \\
\text { dengan cepat } \\
\text { 3. Mandiri Mobile menyediakan contact person untuk } \\
\text { menyelesaikan masalah saya } \\
\text { 4. Jika terjadi kerusakkan sistem Mandiri Mobile dapat } \\
\text { diperbaki dengan cepat }\end{array}$ & Likert \\
\hline 2 & Ease of Use $\left(X_{2}\right)$ & $\begin{array}{l}\text { 1. Mandiri Mobile memberikan instruksi yang jelas } \\
\text { dalam penggunaannya } \\
\text { 2. Mandiri Mobile mudah digunakkan untuk transaksi } \\
\text { 3. Bahasa yang digunaakan dalam Mandiri Mobile } \\
\text { mudah dimengerti } \\
\text { 4. Mandiri Mobile memberikan edukasi dan arahan } \\
\text { dalam penggunaannya }\end{array}$ & Likert \\
\hline 3 & Reliability $\left(X_{3}\right)$ & $\begin{array}{l}\text { 1. Mandiri mobile dapat berfungsi setiap saat } \\
\text { 2. Mandiri mobile memberikan pelayanan yang } \\
\text { konsisten } \\
\text { 3. Mandiri Mobile memberikan catatan yang akurat }\end{array}$ & Likert \\
\hline
\end{tabular}




\begin{tabular}{|c|c|c|c|}
\hline 4 & Convenience $\left(\mathrm{X}_{4}\right)$ & $\begin{array}{l}\text { 1. Mandiri Mobile menyediakan berbagai macam } \\
\text { layanan berbeda } \\
\text { 2. Mandiri Mobile nyaman digunakan } \\
\text { 3. Kecepatan akses Mandiri Mobile cukup baik }\end{array}$ & Likert \\
\hline 5 & Fulfillment $\left(X_{5}\right)$ & $\begin{array}{l}\text { 1. Mandiri Mobile memberikan pemberitahuan } \\
\text { seputar transaksi saya } \\
\text { 2. Mandiri Mobile memberikan catatan bank yang } \\
\text { berkualitas } \\
\text { 3. Mandiri Mobile menyediakan pelayanan yang } \\
\text { cepat }\end{array}$ & Likert \\
\hline 6 & $\begin{array}{l}\text { Security and } \\
\text { Privacy }\left(\mathrm{X}_{6}\right)\end{array}$ & $\begin{array}{l}\text { 1. Saya memiliki kepercayaan dan keyakinan dalam } \\
\text { keamanan Mandiri Mobile } \\
\text { 2. Saya merasa aman saat bertransaksi } \\
\text { menggunakan Mandiri Mobile } \\
\text { 3. Saya yakin terhadap keamanan mengenai } \\
\text { informasi personal saya }\end{array}$ & Likert \\
\hline 7 & $\begin{array}{l}\text { Customer } \\
\text { Satisfaction (Y) }\end{array}$ & $\begin{array}{l}\text { 1. Saya puas dengan Mandiri Mobile } \\
\text { 2. Menurut saya aplikasi mandiri mobile cukup baik } \\
\text { 3. Aplikasi Mandiri Mobile memenuhi ekspektasi saya } \\
\text { 4. Saya merasa senang dengan pengalaman saya } \\
\text { secara keseluruhan menggunakan Mandiri Mobile }\end{array}$ & Likert \\
\hline
\end{tabular}

\section{HASIL PENELITIAN}

Berikut disajikan hasil pengujian hipotesis dari penelitian:

Table 3 Hasil pengujian hipotesis

\begin{tabular}{lrrr}
\hline Variabel & B & t & \multicolumn{1}{c}{ Sig. } \\
\hline (Constant) & 1,486 & 1,272 &, 206 \\
Total_Responsiveness &, 188 & 2,085 &, 039 \\
Total_EOU &, 239 & 2,536 &, 012 \\
Total_Reliability &,- 225 & $-2,141$ &, 034 \\
Total_Convenience &, 290 & 2,368 &, 019 \\
Total_Fulfillment &, 174 & 1,484 &, 140 \\
Total_SP &, 385 & 3,796 &, 000 \\
\hline
\end{tabular}

Berdasarkan tabel di atas didapat bahwa Responsiveness, Kemudahan Penggunaan, Keandalan, Kenyamanan, Keamanan dan Privasi memiliki pengaruh terhadap Kepuasan Pelanggan. Sedangkan Pemenuhan tidak memiliki pengaruh terhadap Kepuasan pelanggan. 


\section{PENUTUP}

Hasil penelitian ini menunjukkan bahwa Responsiveness, Kemudahan Penggunaan, Keandalan, Kenyamanan, Keamanan dan
Privasi memiliki pengaruh terhadap Kepuasan Pelanggan. Sedangkan Pemenuhan tidak memiliki pengaruh terhadap Kepuasan pelanggan.

\section{REFERENSI:}

Asosiasi Penyelenggara Jasa Internet Indonesia (APJII). Penetrasi dan Perilaku Pengguna Internet Indonesia 2016. http://www.apiii.or.id/survei2016

Berry, L.L., Seiders, K. and Grewal, D. 2002. Understanding service convenience. Journal of Marketing, Vol. 66, No. 3: 1-17.

Davis, F.D. (1989). Perceived usefulness, perceived ease of use, and user acceptance of information technology. MIS Quarterly, Vol. 13, №. 3: 318-340.

Parasuraman, A., Zeithaml, V.A. and Berry, L.L. 1988. SERVQUAL: a multiple item scale for measuring consumer perceptions of service quality. Journal of Retailing, Vol. 64, No. 5: 21-40.

Parasuraman, A., Zeithaml, V.A. and Malholtra, A. 2005. E-S-QUAL: a multiple-item scale for assessing electronic service quality. Journal of Service Research, Vol. 7, No. 3: 213-235.

Zeithaml, V.A., Parasuraman, A. and Malhotra, A. 2002. Service quality delivery through websites: a critical review of extant knowledge. Journal of the Academy of Marketing Science, Vol. 30, No. 4: 362-375. 